Article

\title{
Functional Characterization of Outer Membrane Proteins (OMPs) in Xenorhabdus nematophila and Photorhabdus luminescens through Insect Immune Defense Reactions
}

\author{
Reyhaneh Darsouei ${ }^{1}$, Javad Karimi ${ }^{1, * \mathbb{D}}$ and Gary B. Dunphy ${ }^{2}$ \\ 1 Biocontrol and Insect Pathology Lab., Department of Plant Protection, School of Agriculture, Ferdowsi \\ University of Mashhad, Mashhad 9177948974, Iran; rdarsouei@gmail.com \\ 2 Department of Natural Resource Sciences, Faculty of Agricultural and Environmental Sciences, McGill \\ University, 21111 Lakeshore Rd, Ste. Anne de Bellevue, QC H9X 3V9, Canada; gary.dunphy@mcgill.ca \\ * Correspondence: jkb@um.ac.ir; Tel.: +98-51-3880-5817; Fax: +98-51-3878-7430
}

Received: 10 September 2019; Accepted: 6 October 2019; Published: 17 October 2019

\begin{abstract}
Xenorhabdus nematophila and Photorhabdus luminescens are entomopathogenic bacterial symbionts that produce toxic proteins that can interfere with the immune system of insects. Herein, we show that outer membrane proteins (OMPs) could be involved as bacterial virulence factors. Purified totals OMPs of both bacterial species were injected into fifth instar larvae of Spodoptera exigua Hübner. Larvae were surveyed for cellular defenses fluctuations in total haemocyte counts (THC) and granulocyte percentage and for the humoral defenses protease, phospholipase A2 ( $\left.\mathrm{PLA}_{2}\right)$, and phenoloxidase (PO) activities at specific time intervals. Changes in the expression of the three inducible antimicrobial peptides (AMPs), cecropin, attacin, and spodoptericin, were also measured. Larvae treated with OMPs of both bacterial species had more haemocytes than did the negative controls. OMPs of X. nematophila caused more haemocyte destruction than did the OMPs of P. luminescens. The OMPs of both bacterial species initially activated insect defensive enzymes post-injection, the degree of activation varying with enzyme type. The AMPs, attacin, cecropin, and spodoptericin were up-regulated by OMP injections compared with the normal larvae. The expression of these three AMPs was maximal at four hours post injection (hpi) with P. luminescens OMPs treatment. Expression of the three AMPs in X. nematophila treated insects was irregular and lower than in the P. luminescens OMPs treatment. These findings provide insights into the role of OMPs of entomopathogenic nematode bacterial symbionts in countering the physiological defenses of insects.
\end{abstract}

Keywords: antimicrobial peptides; cellular defense; insect pathology; phenoloxidase; phospholipase A2; protease

\section{Introduction}

Xenorhabdus nematophila and Photorhabdus luminescens are gram-negative bacteria (Family Enterobacteriaceae) symbiotically associated with the entomopathogenic nematodes (EPNs), Steinernema carpocapsae Weiser, and Heterorhabditis bacteriophora Poinar, respectively [1]. The EPN infective juvenile stage (IJ) harbors the bacteria in their intestine, releasing them into the haemocoel of the host, causing insect death within $24-48 \mathrm{~h}$ post infection [2]. Several bacterial insecticidal factors characterized in X. nematophila and P. luminescens (Txp40 toxin, Tc toxin, 17-kDa pilin protein) have important roles bacterial virulence and hence EPNs efficacy $[3,4]$, including the pilin protein overcoming host immune activities [5]. 
The pathogenicity of some Gram-negative bacteria depends on their ability to secrete virulence factors into the mammalian host by releasing outer membrane vesicles (OMVs) [6]. Some OMVs virulence factors include phospholipase C, proteases, elastases, hemolysins [6], phospholipids, lipopolysaccharides (LPS) (also known as endotoxins [2]), alkaline protease, and outer membrane integrated membrane proteins (OMPs). In pathogenic bacteria, some OMPs have been identified as virulence factors helping the bacteria escape avoid host defense mechanisms [7]. Inducible OMPs in Xenorhabdus and Photorhabdus were identified, including the stress response proteins skp in P. temperata [8]. Opns, an inducible protein of X. nematophila produces a growth advantage in insect hemolymph [9]. Major defensive factors of insect immune systems are the interactive cellular (haemocyte) and humoral elements. In S. exigua, the major haemocyte types reacting against bacteria include the granulocytes and plasmatocytes [10] which respond to particulate antigens by phagocytosis and nodulation [11]. Humoral factors in this insect species include the synthesis of antimicrobial peptides (AMPs) e.g., cecropins, attacins, the pattern recognition protein lysozyme [12], activation of the prophenoloxidase cascade and phospholipase $\mathrm{A}_{2}\left(\mathrm{PLA}_{2}\right)$ [11].

Due to limited functional information about OMPs of X. nematophila and P. luminescens, the current study was designed to survey the effects of the OMPs on aspects of cellular and humoral defensive enzymes in the haemolymph of S. exigua larvae. We surveyed total haemocyte counts (THC), differential haemocyte counts (DHC), and protease, phospholipase $\mathrm{A}_{2}\left(\mathrm{PLA}_{2}\right)$, and phenoloxidase (PO) activity, as well as the expression patterns of cecropin, attacin, and spodoptericin in response to exposure to total purified OMPs of X. nematophila and P. luminescens.

\section{Materials and Methods}

\subsection{Insect Culture}

Different larval stages of Spodoptera exigua collected from the sugar beet fields at [Mashhad, Razavi Khorasan province ( $\left.36^{\circ} 29^{\prime} \mathrm{N}, 59^{\circ} 60^{\prime} \mathrm{E}\right)$, Northeastern Iran] were reared (under a 16:8 (L:D) $\mathrm{h}$ photoperiod, at R.H. $60 \pm 5 \%$ and $28 \pm 1{ }^{\circ} \mathrm{C}$ in the laboratory) on sugar beet leaves. Moths were fed with $20 \%$ honey solution. The eggs were collected daily. One-day-old larvae were fed with fresh sugar beet leaves and the fifth instar larvae $(0.78 \pm 0.026 \mathrm{mg}$ weight $)$ were used for the experiments.

\subsection{Purification of Outer Membrane Proteins (OMPs)}

\subsubsection{Bacteria Growth}

Photorhabdus luminescens and X. nematophila were isolated from the nematodes H. bacteriophora and S. carpocapsae nematodes (supplied by e nema GmbH company, Schwentinental, Germany), respectively. Bacterial stocks were cultured on NBTA medium containing nutrient agar, triphenyl tetrazolium chloride $(0.004 \% \mathrm{wt} / \mathrm{vol})$, and bromothymol blue $(0.0025 \% \mathrm{wt} / \mathrm{vol})$. For experimental purposes, a $48 \mathrm{~h}$ old colony was transferred into the $100 \mathrm{~mL}$ nutrient broth (NB) medium in a 500 $\mathrm{mL}$ Erlenmeyer and incubated (at $28 \pm 1{ }^{\circ} \mathrm{C}, 120 \mathrm{rpm}$ ) for $24 \mathrm{~h}$. The bacteria were cultured again by adding the $100 \mathrm{~mL}$ culture to a 1 liter volume nutrient broth medium in 5 Erlenmeyer flask with 500 $\mathrm{mL}$ volume) and shaken at $100 \mathrm{rpm}$ on a horizontal shaker $\left(48 \mathrm{~h}\right.$ at $\left.28 \pm 1^{\circ} \mathrm{C}\right)$.

\subsubsection{Preparation of OMPs from Symbiotic Bacteria}

The OMPs were prepared from the culture supernatant as described by Korhonen et al. [13] with modifications. Briefly, after growth for $48 \mathrm{~h}$ in NB, the cells were collected by centrifugation ( $15 \mathrm{~min}$ at $4000 \times g$ ). The pellets were suspended in TEB buffer ( $1 \mathrm{mM}$ benzamidine, $1 \mathrm{mM}$ EDTA pH, 8, $5 \mathrm{mM}$ Tris- $\mathrm{HCl} \mathrm{pH}, 8)$ and homogenized by micropestle. Cell debris was collected by centrifugation ( $5 \mathrm{~min}$ at $2000 \times g$ ) and the supernatant removed. The OMPs in the supernatant were precipitated by adding crystalline ammonium sulfate to $50 \%$ saturation followed with incubation at $4{ }^{\circ} \mathrm{C}$ overnight. The precipitate was collected by centrifugation $(1 \mathrm{~h}$ at $10,000 \times g)$, dissolved in $1 \mathrm{~mL}$ of $5 \mathrm{mM}$ Tris buffer, 
and then dialyzed for $48 \mathrm{~h}$ against $5 \mathrm{mM}$ Tris buffer $(100 \mathrm{~mL})$. Sodium deoxycholate (DOC) $(0.5 \% w / v$, was added to the suspension, which was then dialyzed against $5 \mathrm{mM}$ Tris buffer $(100 \mathrm{~mL})$ containing sodium deoxycholate $(0.5 \% \mathrm{w} / \mathrm{v})$ for $48 \mathrm{~h}$. The suspension was centrifuged for $10 \mathrm{~min}$ at $10,000 \times g$. The pellet contained DOC-insoluble material (outer membrane proteins). OMPs (5 mg) were dissolved in $1 \mathrm{~mL}$ of TENS buffer (50 mM Tris- $\mathrm{HCl}$ [pH 7.2], $400 \mathrm{mM} \mathrm{NaCl}, 5 \mathrm{mM}$ EDTA, 1\% sodium dodecyl sulfate). The concentration of OMPs were determined by the Bradford method using the standard curve of BSA. Their molecular weight was estimated by sodium dodecyl sulfate polyacrylamide gel electrophoresis (SDS-PAGE). SDS-PAGE was stained with Coomassie Blue dye.

\subsection{Injection of Bacterial OMPs}

The fifth instar larvae of S. exigua were injected with $5 \mu \mathrm{L} \mathrm{OMPs}(0.6 \mathrm{mg} / \mathrm{mL})$ in TENS buffer using an insulin syringe (30 G, B. Braun; Melsungen, Germany). Negative control larvae received $5 \mu \mathrm{L}$ TENS buffer. In the gene expression experiment, a treatment without injection was considered as the normal sample. Larvae were subsequently kept at room temperature and fed with fresh leaves. The different aspects of the immune defenses were surveyed using at $0.5,2,4,8,12$, and 16-h post-injection (hpi).

\subsection{Total Haemocyte Counts and Differential Haemocyte Counts (THC and DHC)}

For THC assay, the surface of injected larvae was disinfected with $70 \%$ ethanol. Five $\mu \mathrm{L}$ of hemolymph were collected by cutting the prothoracic leg. Haemocytes were counted on a Neubauer hemocytometer (Marienfeld, Lauda-Königshofen, Germany). Haemocyte numbers were calculated based on Jones's formula [14]. For DHC, haemolymph $(10 \mu \mathrm{L})$ was smeared on the glass microscope slide. The cells were fixed with acetic acid: methanol $(1: 3 v / v)$ for 5 min [15] and stained with $10 \%(v / v)$ Giemsa [16]. One hundred haemocytes were counted randomly and haemocyte types were determined according to Ribeiro and Brehelin [17] and recorded as a percentage of total cells.

\subsection{Protease Assay}

For total protease activities of S. exigua larval haemolymph, azocasein (Sigma, Taufkirchen, Germany) was used as a substrate and the absorbance was determined at $450 \mathrm{~nm}$ on a microplate reader (Stat Fax 3200 ${ }^{\circledR ;}$; Awareness Technology Inc., Palm, FL, USA). $48.5 \mu \mathrm{L}$ Tris buffer (pH 9), $16.5 \mu \mathrm{L}$ azocasein $3 \%$, and $10 \mu \mathrm{L}$ haemolymph were kept at $37^{\circ} \mathrm{C}$ for $2 \mathrm{~h}$. After adding $50 \mu \mathrm{L}$ of $30 \%$ trichloroacetic acid, the protease activity was stopped. The samples were incubated at $4{ }^{\circ} \mathrm{C}$ for $30 \mathrm{~min}$, the centrifuged at $10,000 \times g$ for $10 \mathrm{~min}$ and $100 \mu \mathrm{L}$ of the supernatant mixed with $\mathrm{NaOH} 1 \mathrm{M}(100 \mu \mathrm{L})$. The activity of protease was expressed as $\mu \mathrm{mol}$ dye $/ \mathrm{min} / \mathrm{mg}$ protein using the extinction coefficient of the chromogenic azo group produced by the cleavage of casein [18].

\subsection{Phospholipase $A_{2}\left(P L A_{2}\right)$ Assay}

The PLA 2 was assayed using a modification of Radvanyi et al. [19]. Pyrene-labeled phospholipid (Sigma) was used as a substrate. The PLA 2 activity was calculated by spectrofluotometry (Cecil CE9500, Millersville, PA, USA) and the fluorescence intensity recorded using excitation and emission wavelengths of 345 and $398 \mathrm{~nm}$, respectively.

\subsection{Phenoloxidase (PO) Assay}

For phenoloxidase activity, L-dihydroxyphenylalanine (L-Dopa, Sigma) was used as a substrate. Hemolymph was centrifuged $\left(2000 \times g, 4{ }^{\circ} \mathrm{C} 1 \mathrm{~min}\right)$ and the supernatant plasma was used as the enzyme source. One hundred $\mu \mathrm{L}$ L-Dopa $(60 \mathrm{mM}), 90 \mu \mathrm{L}$ phosphate buffer $(\mathrm{pH} 8.6)$ and $10 \mu \mathrm{L}$ supernatant were added to microplate wells. An increase in absorbance was recorded every $30 \mathrm{~s}$ over $5 \mathrm{~min}$ at $492 \mathrm{~nm}$ using a Stat Fax 3200 Microplate Reader. One unit of PO activity was defined as the amount of enzyme that oxidizes $1 \mathrm{~mol}$ of L-Dopa per min per $\mathrm{mg}$ total plasma protein at room temperature 
$\left(25 \pm 2{ }^{\circ} \mathrm{C}\right)$. Total protein concentration was estimated according to the Bradford method [20]. Different concentrations of BSA were used in the standard curve [21].

\subsection{Gene Expression}

\subsubsection{RNA Extraction and cDNA Synthesis}

Total RNA was extracted from haemolymph of the larvae at 2, 4, 8, and 16-h post injection using RNA extraction kit (catalogue number A101231 following the manufacturer's instructions, Pars tous company, Tehran, Iran) then were treated with DNase I (catalogue number MO5401, Sina colon company, Tehran, Iran) according to the manufacturer's instructions. The first-standard cDNA was synthesized with $1 \mu \mathrm{g}$ of total RNA, oligo-dt primers, and reverse transcriptase according to the manufacturer's protocol.

\subsubsection{Design and Synthesis of Primers}

For AMPs expression of the target genes, attacin, cercopin, and spodoptericin, a set of primers were designed and used. Elongation factor 2 (EF2) gene was the reference gene used for normalization [22].

\subsubsection{Quantitative PCR (qPCR)}

qRT-PCR reactions were carried out in optical 8-cap strips (BioRad, California, CA, USA) on a BioRad machine model CFX96 using the 2X SYBR Green master mix. The total reaction volume $(20 \mu \mathrm{L})$ contained $10 \mu \mathrm{L}$ of SYBR Green, $0.2 \mu \mathrm{L}$ of both the forward and reverse primers, and $2 \mu \mathrm{L}$ of cDNA (1 $\mu \mathrm{g}$ concentration). The PCR conditions consisted of $95^{\circ} \mathrm{C}$ for $10 \mathrm{~min} ; 40$ cycles of $95^{\circ} \mathrm{C}$ for $15 \mathrm{~s}$, $65^{\circ} \mathrm{C}$ for $30 \mathrm{~s}$, and $72{ }^{\circ} \mathrm{C}$ for $30 \mathrm{~s}$, followed by a melt curve analysis at $95^{\circ} \mathrm{C}$ for $10 \mathrm{~s}$. Subsequently a temperature transition rate of $0.5^{\circ} \mathrm{C} / \mathrm{s}$ was performed from 50 to $95^{\circ} \mathrm{C}$. The cycle threshold (CT) values were determined by CFX 96 software. The relative expression ratios of the target gene in treated groups were calculated using a $2^{-\Delta \Delta C T}$ method [23]. All assays were performed on two independent replicates.

\subsection{Statistical Analysis}

The data were analyzed using two-way ANOVA (SAS Institute, [24]). Here, OMPs and time intervals were the two main effects. The effect of either factor alone and interactive effect (OMPs types $\times$ times interval) were calculated. When a significant result for the ANOVA was obtained $(p<0.05)$, a slicing test was used to measure the significant difference between means. Prior to ANOVA analysis, data were assessed for the assumption of ANOVA normality and homogeneity of variance (SAS Institute, [24]). All graphic data indicate the mean \pm standard error (SE) of the mean in each treatment. The experiments were done at least two times with four insects for each experiment.

\section{Results}

\subsection{Outer Membrane Protein Profiles}

The OMPs profiles of X. nematophila and P. luminescens differed. The protein diversity in X. nematophia was more than that of $P$. luminescens (Figure 1). Protein with a molecular mass of $\sim 35-40 \mathrm{kDa}$ was more abundant of $X$. nematophila than other proteins. The total extracted protein concentration for the same amounts of X. nematophila and P. luminescens was 1.075 and $1.554 \mathrm{mg} / \mathrm{mL}$, respectively. Also, the 260/280 ratio in X. nematophila and P. luminescens was 1.12 and 1.07 , respectively. The concentration of OMPs in X. nematophila and P. luminescens using Bradford method was $0.84 \pm 0.1$ and $0.64 \pm 0.1(\mathrm{mg} / \mathrm{mL})$, respectively. 


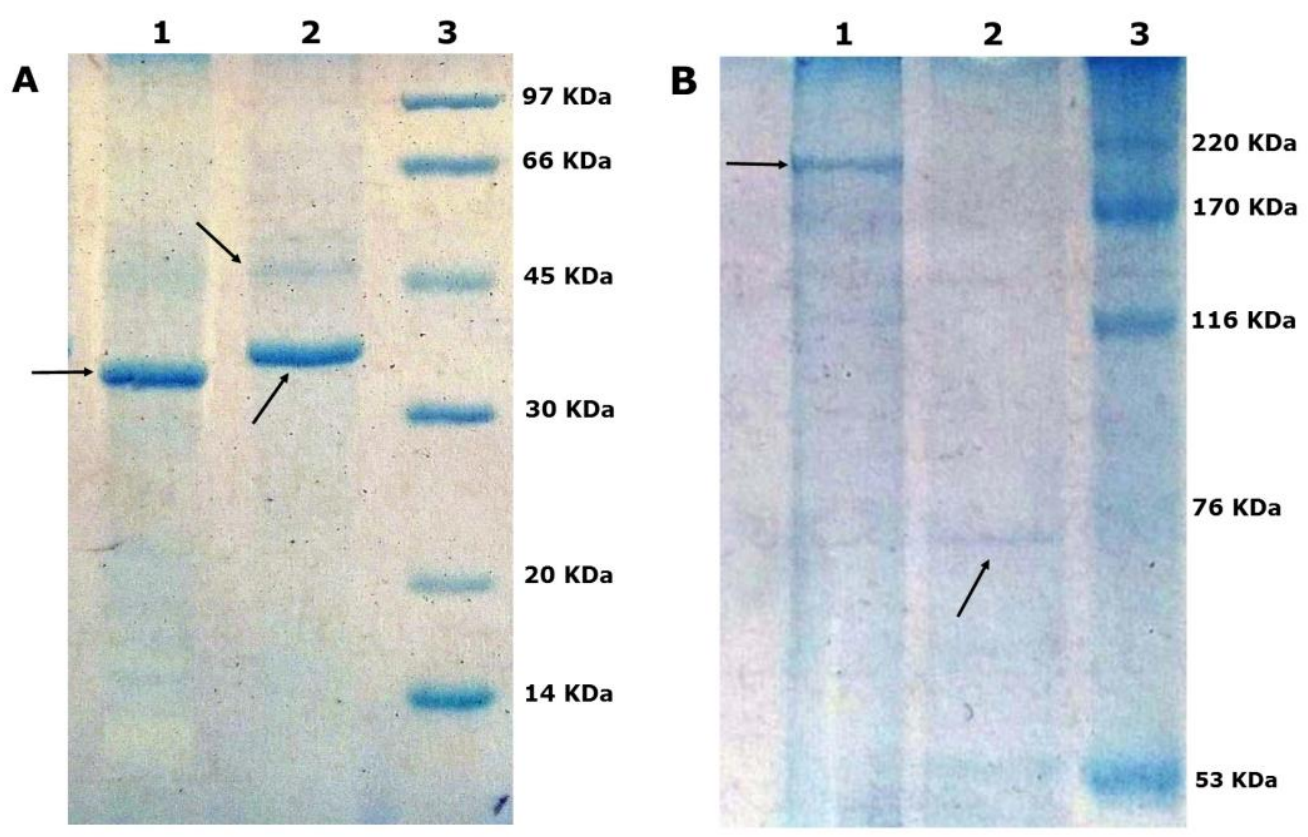

Figure 1. Coomassie blue dye stained SDS-PAGE gels showing the outer membrane proteins, (1) Xenorhabdus nematophila, (2) Photorhabdus luminescens, (3) Standard. (A) The molecular weight 14-97 $\mathrm{kDa},(B)$ The molecular weight 53-220 kDa. Protein fragments have shown with arrows.

\subsection{Total Haemocyte Count}

There were differences in effects total of OMPs on THC depending on the bacterial species and incubation times $\left(\mathrm{F}_{10,126}=3.37, p<0.05\right)$. The OMPs $\left(\mathrm{F}_{2,126}=24.61, p<0.05\right)$ and time post-injection $\left(\mathrm{F}_{5,126}=5.67, p<0.05\right)$ significantly affected THC values (Figure $2 \mathrm{~A}$ ). In larvae with P. luminescens OMPs, the haemocytes levels were generally greater than those caused by X. nematophila OMPs, however, the rate of the decline in THC in larvae with X. nematophila OMPs was faster than those with P. luminescen OMPs (Figure 2A). Compared with the control treatment constant THC values, the THC levels in larvae with $P$. luminescens OMPs increased to maximum level at $2 \mathrm{hpi}\left(2 \mathrm{h:} \mathrm{F}_{1,14}=22.11, p<0.05\right)$ then decreased from 4-16 hpi (4 h: $\mathrm{F}_{1,14}=7.81, p<0.05 ; 8 \mathrm{~h}: \mathrm{F}_{1,14}=34.71, p<0.05 ; 12 \mathrm{~h}: \mathrm{F}_{1,14}=17.53$, $p<0.05 ; 16$ h: $\left.\mathrm{F}_{1,14}=3.89, p<0.05\right)$. With the exception of $0.5 \mathrm{hpi}$, P. luminescens OMPs elevated THC above the control counts. X. nematophila OMPs elevated THC levels to a maximum count by $4 \mathrm{hpi}(4 \mathrm{~h}$ : $\left.\mathrm{F}_{1,14}=16.91, p<0.05\right)$ more slowly than did P. luminescens OMPs, the levels then decreased. There was a significant difference between X. nematophila OMPs and control treatment in THC density by 0.5 and 4 hpi $\left(0.5\right.$ h: $\mathrm{F}_{1,14}=2.2, p<0.05 ; 2$ h: $\left.\mathrm{F}_{1,14}=16.46, p<0.05 ; 4 \mathrm{~h}: \mathrm{F}_{1,14}=16.91, p<0.05\right)$. While in larvae with $P$. luminescens OMPs, a significant difference was observed compared with the negative control occurred from 2 to 16 hpi $\left(2 \mathrm{~h}: \mathrm{F}_{1,14}=22.11, p<0.05 ; 4 \mathrm{h:} \mathrm{F}_{1,14}=7.81, p<0.05 ; 8\right.$ h: $\mathrm{F}_{1,14}=34.71$, $p<0.05 ; 12$ h: $\mathrm{F}_{1,14}=17.53, p<0.05 ; 16$ h: $\mathrm{F}_{1,14}=3.89, p<0.05$ ) (Figure $2 \mathrm{~A}$ ). 

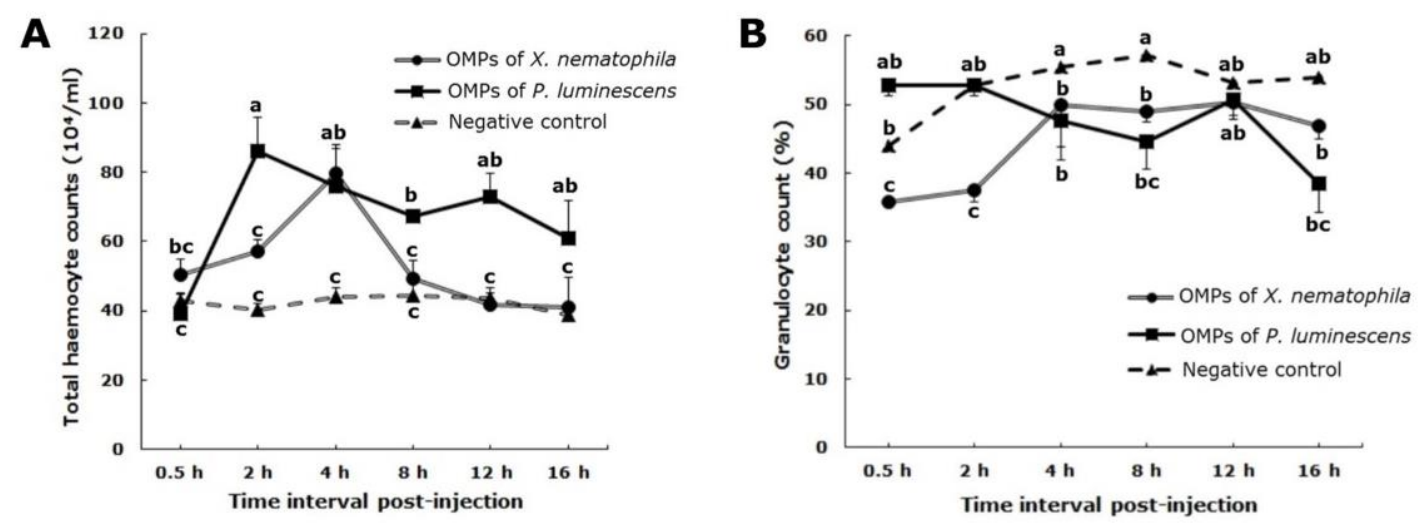

Figure 2. Changes in the patterns of cellular defense elements in fifth instar larvae of Spodoptera exigua after injection with outer membrane proteins of either Xenorhabdus nematophila or Photorhabdus luminescens, (A) total haemocyte count, (B) granulocyte percentage. Each measurement consists of eight replications. The vertical bars represent the standard error of the means. Different letters above the error bars indicate a significant difference of interactive effect means between outer membrane proteins from the two bacterial species $\times$ interval times at $\alpha=0.05$ (Slicing test).

\subsection{Granulocyte Counts}

There was a significant interactive effect on granulocytes between OMPs of both bacterial species over time (OMPs $\times$ times) $\left(\mathrm{F}_{10,126}=2.76, p<0.05\right)$. Although the granulocyte percentages between OMPs types were not significantly different $\left(\mathrm{F}_{2,126}=1.26, p>0.05\right)$, analysis of granulocytes data over time intervals $\left(\mathrm{F}_{3,126}=148.46, p<0.05\right)$ indicated there was a significant difference among specific times (Figure 2B).

In larvae with P. luminescens OMPs, the granulocyte percentages from 4 to $16 \mathrm{hpi}$ were less than the negative control values $\left(4 \mathrm{~h}: \mathrm{F}_{1,14}=4.87, p<0.05 ; 8 \mathrm{~h}: \mathrm{F}_{1,14}=3.09, p<0.05 ; 12 \mathrm{~h}: \mathrm{F}_{1,14}=1.37, p>0.05\right.$; $\left.16 \mathrm{~h}: \mathrm{F}_{1,14}=0.48, p>0.05\right)$. The percentage of granulocytes in larvae with OMPs of X. nematophila was always less than the negative control. However, the granulocyte percentage for both spp. increased to a maximum plateau density by $4 \mathrm{hpi}\left(0.5 \mathrm{~h}: \mathrm{F}_{1,14}=0.01, p>0.05 ; 2 \mathrm{~h} \mathrm{~F}_{1,14}=2.66, p>0.05 ; 4 \mathrm{~h}\right.$ : $\mathrm{F}_{1,14}=1.57, p>0.05$ ). There was a significant difference in the number of granulocytes by $0.5 \mathrm{hpi}$ after injection OMPs of X. nematophila and P. luminescens $\left(0.5 \mathrm{~h}: \mathrm{F}_{1,14}=15.85, p<0.05 ; 2 \mathrm{~h}: \mathrm{F}_{1,14}=3.77 .1\right.$, $p>0.05 ; 4$ h: $\mathrm{F}_{1,14}=0.06, p>0.05 ; 8$ h: $\mathrm{F}_{1,14}=0.95, p>0.05 ; 12$ h: $\mathrm{F}_{1,14}=0.02, p>0.05 ; 16$ h: $\mathrm{F}_{1,14}=3.27$, $p>0.05$ ) (Figure 2B).

The changes in levels of other haemocytes, including plasmatocytes, spherulocytes, and oenocytoides, were calculated. In larvae with X. nematophila OMPs, plasmatocytes, and spherulocytes percentages were more than those in the negative control insects, their trends in during time were irregular. There were no oenocytoids in the haemolymph. In larvae with P. luminescens OMPs treatments, the highly irregular fluctuation plasmatocyte densities at 8-12 hpi were more than in the negative control group (Figures S1 and S2). The spherulocytes percentage, from 2-16 hpi, was more than in the control larvae and exhibited irregular fluctuation (Figures S3 and S4). The average of oenocytoids were less than one haemocyte (Figures S5 and S6).

\subsection{General Protease Activity}

The total protease activity interactive effect between OMP types and intervals time was significant $\left(\mathrm{F}_{10,54}=2.63, p<0.05\right)$ for bacterial species both OMP $\left(\mathrm{F}_{2,54}=68.06, p<0.05\right)$ and time intervals $\left(\mathrm{F}_{5,54}=4.72, p<0.05\right)$ (Figure 3A). Larvae with OMPs of $P$. luminescens exhibited an increase protease activity from $0.5 \mathrm{hpi}$, reaching a maximizing level at $8 \mathrm{hpi}$, which then decreased. This activity was higher than in the negative control insects during this time interval $\left(0.5 \mathrm{~h}: \mathrm{F}_{1,6}=28.12, p<0.05 ; 2 \mathrm{~h}\right.$ : $\mathrm{F}_{1,6}=23.25, p<0.05 ; 4$ h: $\mathrm{F}_{1,6}=77.99, p<0.05 ; 8$ h: $\mathrm{F}_{1,6}=203.06, p<0.05 ; 12$ h: $\mathrm{F}_{1,6}=9.71, p<0.05$; 
16 h: $\left.\mathrm{F}_{1,6}=0.26, p>0.05\right)$. X. nematophila OMPs, protease activity was statistically comparable with those in the control larvae, except for the absence of an increase at 4 hpi and a decline by 16 hpi ( 4 h: $\mathrm{F}_{1,6}=24.44, p<0.05 ; 16 \mathrm{~h}: \mathrm{F}_{1,6}=41.86, p<0.05$ ) (Figure 3A). Protease activity was significantly different between both OMPs types by 2-16 hpi $\left(0.5 \mathrm{~h}: \mathrm{F}_{1,6}=4.02, p>0.05 ; 2 \mathrm{~h}: \mathrm{F}_{1,6}=26.51, p<0.05\right.$; 4 h: $\mathrm{F}_{1,6}=2453.23, p<0.05 ; 8$ h: $\mathrm{F}_{1,6}=46.58, p<0.05 ; 12 \mathrm{~h}: \mathrm{F}_{1,6}=31.02, p<0.05 ; 16$ h: $\mathrm{F}_{1,6}=8.61$, $p<0.05)$. Larvae treated with both OMP types had the same pattern of increasing protease activity from 0.5 to a peak at $8 \mathrm{hpi}$ and thereafter declining, albeit it at different rates.
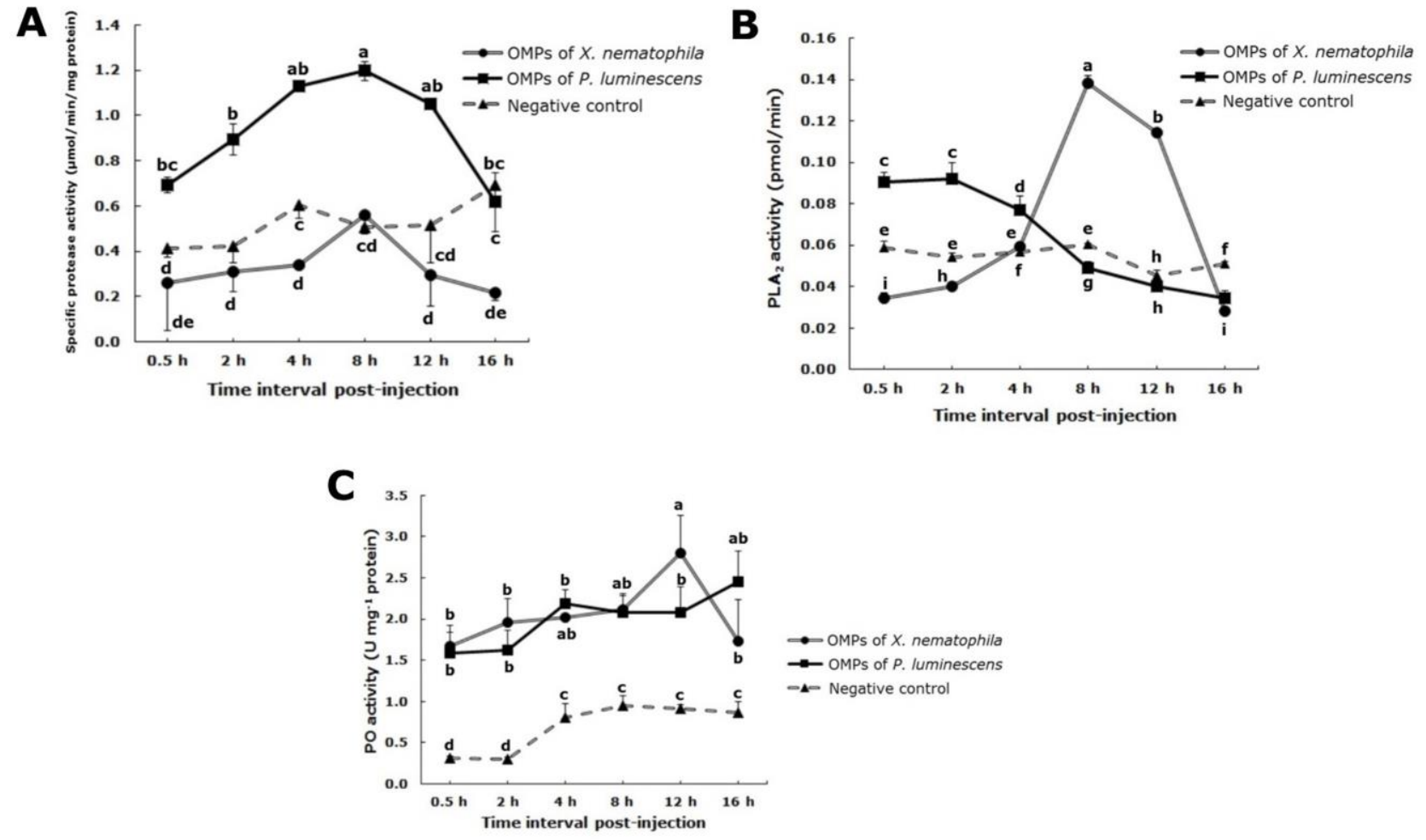

Figure 3. Changes in the patterns of humoral defense elements in fifth instar larvae of Spodoptera exigua after injection with outer membrane proteins of Xenorhabdus nematophila or outer membrane proteins of Photorhabdus luminescens, (A) protease, (B) phospholipase A2, (C) phenoloxidase. Each measurement consists of eight replications. The vertical bars represent the standard error of the means. Different letters above the error bars indicate a significant difference of interactive effect means between outer membrane proteins from the two bacterial species $\times$ interval times at $\alpha=0.05$ (Slicing test).

\subsection{Phospholipase $A_{2}$ Assay}

Interaction between OMPs and time intervals exerted a significant effect on PLA 2 activity (Figure 3B). PLA 2 activity in larvae with OMPs of P. luminescens, although constant from 0.5 to 2 hpi, thereafter decreased, and by 8 to 16 hpi the enzyme activity was less than the control. Larvae with $P$. luminescens OMPs exhibited statistically altered PLA 2 activity compared with control larvae except at $12 \mathrm{hpi}$, at which time activities were similar $\left(0.5 \mathrm{~h}: \mathrm{F}_{1,2}=32.23, p<0.05 ; 2 \mathrm{h:} \mathrm{F}_{1,2}=164.95, p<0.05 ; 4\right.$ h: $\mathrm{F}_{1,2}=287.99, p<0.05 ; 8$ h: $\mathrm{F}_{1,2}=763.60, p<0.05 ; 12$ h: $\mathrm{F}_{1,2}=862.95, p<0.05 ; 16$ h: $\mathrm{F}_{1,2}=758.43$, $p<0.05)$. In larvae with $X$. nematophila OMPs, the PLA 2 level increased to a maximum value at 8 hpi and declined by $16 \mathrm{hpi}$ to values less than the negative control levels $\left(0.5 \mathrm{~h}: \mathrm{F}_{1,2}=494.29, p<0.05 ; 2\right.$ h: $\mathrm{F}_{1,2}=1977.05, p<0.05 ; 4$ h: $\mathrm{F}_{1,2}=3580.53, p>0.05 ; 8$ h: $\mathrm{F}_{1,2}=174.28, p<0.05 ; 12$ h: $\mathrm{F}_{1,2}=369.49$, $p<0.05 ; 16 \mathrm{~h}: \mathrm{F}_{1,2}=2763.84, p<0.05$ ) (Figure 3B). There was a significant difference between the effect of bacterial OMPs sources on PLA 2 activity $\left(0.5 \mathrm{~h}: \mathrm{F}_{1,2}=136, p<0.05 ; 2 \mathrm{~h}: \mathrm{F}_{1,2}=54.13, p<0.05 ; 4 \mathrm{~h}\right.$ : $\mathrm{F}_{1,2}=7.16, p>0.05 ; 8 \mathrm{~h}: \mathrm{F}_{1,2}=325.54, p<0.05 ; 12 \mathrm{~h}: \mathrm{F}_{1,2}=312.46, p<0.05 ; 16$ h: $\left.\mathrm{F}_{1,2}=2.12, p>0.05\right) ; P$. luminescens OMPs effect from 0.5 to 4 hpi being higher than for X. nematophila OMPs and the latter 
being greater than the former from 8-12 hpi. Control values were constant throughout the test times. Both source of OMPs inhibited PLA2 activity, the kinetic varying with the bacterial species.

\subsection{Phenoloxidase Assay}

There was no evidence of significant interactive effect between OMP bacterial species and times on PO activity $\left(\mathrm{F}_{10,54}=1.43, p>0.05\right)$ (Figure 3C). Control larvae exhibited a marginal increase in PO activity by $4 \mathrm{hpi}$, followed by a plateau. The control $\mathrm{PO}$ values were significantly less than either OMP types at all sample times. There was no significant difference in PO activity in larvae with $P$. luminescens OMPs versus control from 0.5 to 16 hpi $\left(0.5\right.$ h: $\mathrm{F}_{1,6}=26.53, p<0.05 ; 2 \mathrm{~h}: \mathrm{F}_{1,2}=28.33, p<0.05$; $4 \mathrm{~h}: \mathrm{F}_{1,2}=112.64, p<0.05 ; 8 \mathrm{~h}: \mathrm{F}_{1,2}=55.42, p<0.05 ; 12 \mathrm{~h}: \mathrm{F}_{1,2}=32.14, p<0.05 ; 16$ h: $\mathrm{F}_{1,2}=31.45$, $p<0.05)$. However, $\mathrm{PO}$ activity in larvae with $X$. nematophila OMPs increased gradually, reaching a maximum value by $12 \mathrm{hpi}$ and then decreased $\left(0.5 \mathrm{~h}: \mathrm{F}_{1,6}=29.66, p<0.05 ; 2 \mathrm{~h}: \mathrm{F}_{1,2}=31.30, p<0.05\right.$; 4 h: $\mathrm{F}_{1,2}=983, p<0.05 ; 8$ h: $\mathrm{F}_{1,2}=113.08, p<0.05 ; 12 \mathrm{~h}: \mathrm{F}_{1,2}=32.05, p<0.05 ; 16$ h: $\left.\mathrm{F}_{1,2}=7.20, p<0.05\right)$ (Figure 3C). There was no significant difference between OMPs of $X$. nematophila and $p$. luminescens on PO activation ( $0.5 \mathrm{~h}: \mathrm{F}_{1,6}=0.05, p>0.05 ; 2 \mathrm{h:} \mathrm{F}_{1,6}=0.77, p>0.05 ; 4 \mathrm{~h}: \mathrm{F}_{1,6}=1.11, p>0.05 ; 8 \mathrm{~h}$ : $\mathrm{F}_{1,6}=0.03, p>0.05 ; 12$ h: $\mathrm{F}_{1,6}=1.75, p>0.05 ; 16$ h: $\left.\mathrm{F}_{1,6}=1.34, p>0.05\right)$.

\subsection{Attacin Gene Expression}

The effect of OMPs of $P$. luminescens and X. nematophila on fluctuation of the attacin expression in S. exigua larvae was significant $\left(\mathrm{F}_{1,8}=25,737.1, p<0.05\right)$ and varied with the bacterial species (Figure 4A). In larvae with $P$. luminescens OMPs, attacin expression value gradually increased from 2 hpi to a maximum level at 4 hpi $\left(4 \mathrm{~h}: \mathrm{F}_{1,2}=9446, p<0.05\right)$ then decreased by 8 hpi $\left(16 \mathrm{~h}: \mathrm{F}_{1,2}=3.36\right.$, $p>0.05$ ). Attacin expression in larvae with X. nematophila OMPs was less than those with OMPs of $P$. luminescens and reached a maximum level with $96.86 \pm 1.14$-fold greater than the negative control by 2 hpi. Thus, the attacin gene was upregulated by OMP of both bacterial species, but the degree of upregulation varied with the source of total OMP. The gene expression in injected larvae with control buffer was 0.39-0.5 times higher than the normal sample (non-injected larvae). There was a significant difference between the effect of both bacterial species on attacin expression ( $2 \mathrm{~h}: \mathrm{F}_{1,2}=477.80, p<0.05$; 4 h: $\mathrm{F}_{1,2}=9308, p<0.05 ; 8 \mathrm{~h}: \mathrm{F}_{1,2}=6009.70, p<0.05 ; 16$ h: $\mathrm{F}_{1,2}=1403.56, p<0.05$ ) (Figure 4A). The total OMPs from both bacterial species were able to decrease attacin expression.

\subsection{Cecropin Gene Expression}

There were significant fluctuations of cecropin expression in S. exigua larvae with different OMPs sources over time $\left(\mathrm{F}_{1,8}=1706, p<0.05\right)$ (Figure $\left.4 \mathrm{~B}\right)$. Also, interactive effects between both bacterial OMPs and time $\left(\mathrm{F}_{3,8}=141.32, p<0.05\right)$ in larvae with P. luminescens OMPs, cecropin expression elevated gradually from 2 hpi to the highest level at 4 hpi $\left(4 \mathrm{~h}: \mathrm{F}_{1,2}=1921.02, p<0.05\right)$ and then decreased ( $8 \mathrm{~h}: \mathrm{F}_{1,2}=0, p>0.05 ; 16 \mathrm{~h}: \mathrm{F}_{1,2}=38.27, p<0.05$ ). The expression pattern of the cecropin gene in larvae with $X$. nematophila OMPs was similar to those of $P$. luminescens OMPs. However, cecropin expression in larvae with OMPs X. nematophila was less than those of treated with P. luminescens OMPs. The cecropin expression in injected larvae with both OMPs was positive. However, the ability of OMPs of X. nematophila to decrease cecropin expression was more than P. luminescens OMPs from 4 to $16 \mathrm{hpi}$. The gene expression in larvae injected with control buffer was $0.03-0.05$ times higher than the normal sample. There was a significant difference between OMPs of X. nematophila and $P$. luminescens on cecropin expression at 2 and 16 hpi $\left(2 \mathrm{~h}: \mathrm{F}_{1,2}=65.8, p<0.05 ; 4 \mathrm{~h}: \mathrm{F}_{1,2}=169.12, p<0.05\right.$; $8 \mathrm{~h}: \mathrm{F}_{1,2}=143.08, p<0.05 ; 16 \mathrm{~h}: \mathrm{F}_{1,2}=59.02, p<0.05$ ) (Figure $4 \mathrm{~B}$ ). Both OMPs types were able to decrease cecropin expression. 

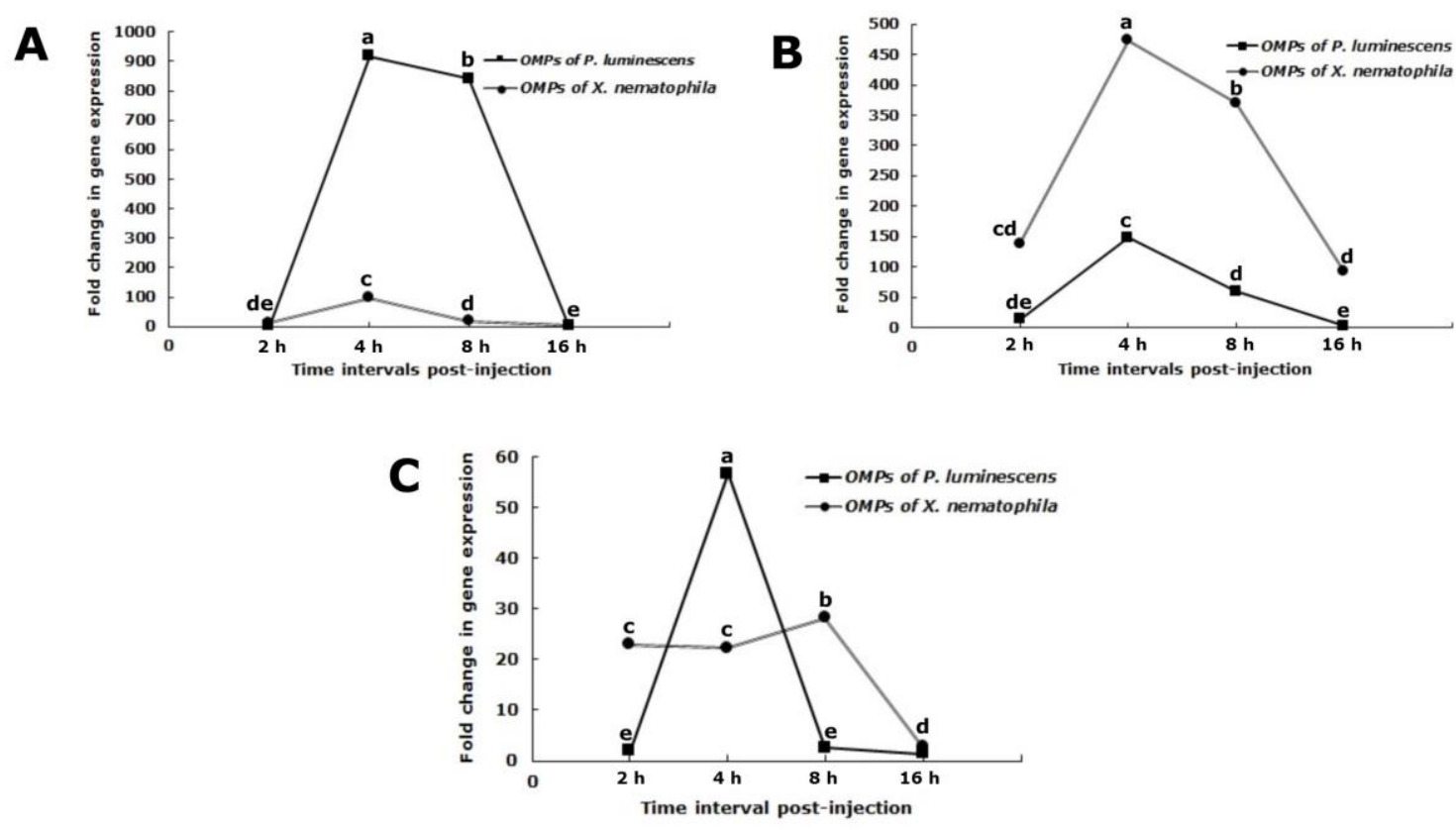

Figure 4. Changes in the patterns of the expression of selected inducible antimicrobial genes in fifth instar larvae of Spodoptera exigua after injection with outer membrane proteins of Xenorhabdus nematophila or outer membrane proteins of Photorhabdus luminescens, (A) attacin, (B) cecropin, (C) spodoptericin. Each measurement consists of eight replications. The vertical bars represent the standard deviations of the means. Different letters above the error bars indicate a significant difference of interactive effect means between outer membrane proteins types $\times$ interval times at $\alpha=0.05$ (Slicing test).

\subsection{Spodoptericin Gene Expression}

There was a significant interactive effect between both bacterial OMPs and time $\left(\mathrm{F}_{3,8}=289.26\right.$, $p<0.05)$. Also, bacterial OMPs $\left(\mathrm{F}_{1,3}=17.90, p<0.05\right)$ during different times $\left(\mathrm{F}_{3,8}=387.15, p<0.05\right)$ significantly affected the expression of spodoptericin (Figure 4C). Spodoptericin expression in larvae with $P$. luminescens OMPs compared with the negative control reached the maximum level by $4 \mathrm{hpi}$ $\left(4 \mathrm{~h}: \mathrm{F}_{1,2}=873.98, p<0.05\right)$ and then decreased $\left(8 \mathrm{~h}: \mathrm{F}_{1,2}=10.45, p>0.05 ; 16 \mathrm{~h}: \mathrm{F}_{1,2}=47.82, p<0.05\right)$. In larvae with $X$. nematophila OMPs, a gradual decrease of spodoptericin occurred from 8 to $16 \mathrm{hpi}$ (16 h: $\mathrm{F}_{1,2}=3.15, p>0.05$ ). The change of spodoptericin gene activity was positive during early expose to the protein, revealing that gene is up-regulated (Figure $4 \mathrm{C}$ ). Then, both bacterial OMPs were able to decrease spodoptericin expression. The trend of induced spodoptericin in larvae with X. nematophila OMPs and P. luminescens OMPs differed.

\section{Discussion}

In the current study, the cellular and humoral aspects of the immune system in S. exigua larvae against purified total OMPs of X. nematophila and P. luminescens were uniquely considered. The results imply that OMPs of the bacteria were able to modulate both the cellular and humoral defenses, the different OMP responses representing different types or amounts of the modulating components from the two bacteria species. The OMPs of these insect pathogenic bacteria likely contribute to their virulence. The OMPs of mammalian pathogenic bacteria serve as virulence elements for the evasion of the immune of the host [7]. Interesting and puzzling is that gene expression in the present recent study was influenced sooner than cellular and early stage humoral factors, even though humoral cytokines activate traditional cellular responses by influencing cellular signaling pathways, and elicit AMPs production independently or after host cellular responses [25]. THC and granulocyte levels of S. exigua after injection of X. nematophila OMPs and P. luminescens OMPs decreased at different times early in the post inoculation phase. This could be attributed to LPS-contaminated OMPs eliciting 
apoptotic symptoms in the haemocytes by of the releasing of LPS [26]. The decline in the density of all haemocyte types in Galleria mellonella Linneaus larvae resulted from the lipid A moiety of X. nematophila and P. luminescence LPS action triggering haemocytes lysis (including oenocytoids) and inhibiting PO activation but not activity [27]. Herein, OMP components activate PO directly or indirectly by lysis oenocytoids, and releasing the enzyme, as reported for S. exigua [28]. However, unlike the effect of LPS on G. mellonella, in S. exigua with OMPs, there was no correlation between PO activity and oenocytoid density. In larvae with OMPs of both bacterial species, PO activity increased over the incubation time, but in the treatments with $X$. nematophila OMPs it decreased after the peak. We assume the decrease PO in larvae with X. nematophila OMPs was caused by OMPs. Collectively, the effects of OMPs on the hemocytes and continuous activation of PO imply that there were no physiological amounts of LPS on the purified OMPs in the present study. Comparing protease activity in OMP treated larvae with the negative larva controls was activated over time using OMP from both bacterial types, the magnitude being greater for P. luminescence than X. nematophila, the latter being similar to the control. In treated larvae with OMPs of X. nematophila, the protease activity at the beginning of injection was less than the negative control.

Park and Kim [11] and Park et al. [10] confirmed that intact X. nematophila in S. exigua was able to decrease $\mathrm{PLA}_{2}$ activity, limiting cellular immunity. In the present study, $\mathrm{PLA}_{2}$ activity relative to the constant control levels increased in the early post-inoculation stages and decreased after maximum activity later in the cycle. The differences could be related to variations in the types of OMP components, their amounts, biological properties, and spatial organization in the total OMP extracts. Here it is confirmed that protein profiles of $X$. nematophila and $P$. luminesces are different. The lower ability of $P$. luminescens OMPs on haemocytes destruction, inhibition of PO activity, and decrease of some humoral elements in initial times are in accordance with Forst and Nealson [8], who indicated as in the present work, that the surface of Photorhabdus spp. may be different from of Xenorhabdus spp. The importance of cell surface properties in the life cycle and phase variation of Xenorhabdus cells has been linked to identified outer membrane proteins such as fimbria (pilin) and flagella [29]. Although the properties of OMPs, flagella in phase I and phase II cells, fimbria (pilin) protein of surveyed X. nematophila are known [30], the cell surface properties of Photorhabdus cells have been more limited to OMPs [8,31,32].

Here it is reported that in S. exigua larvae the AMPs attacin, cecropin, and spodoptericin genes are activated by the OMPs. Bacterial LPS activates numerous types of AMPs in Lepidoptera [33]. While OMPs and LPS effects may confer resistance to the bacteria by the host insect, Duperthuy et al. [34] established that outer membrane protein $U(\mathrm{OmpU})$ of Vibrio splendidus, the oyster pathogenic bacterium, contributes to its virulence by making the bacterium resistant to antimicrobial peptides. Vanaja et al. [35], reported that OMVs of extracellular Gram-negative mammalian bacteria can deliver LPS into the host cells; however, the mechanism of LPS translocation remains unclear.

Herein, OMPS of both X. nematophila and P. luminescens upregulated attacin and cecropin for the expression of these AMPs by X. nematophila OMPs being less than P. luminescens. This phenomenon may be due to differences in OMP composition. Spodoptericin is expressed in lepidopteran insects with Gram-positive bacteria [36]. In the present work, spodoptericin was expressed after injection of OMPs from both Gram-negative bacteria.

The pronounced irregulars' fluctuations of attacin and cecropin occurred in larvae with OMPs of X. nematophila. Whereas, AMPs expression in larvae with P. luminescens OMPs reached the maximum level by $4 \mathrm{hpi}$ and then decreased. According to Castillo et al. [37], the expression level of cecropinA1/A2 in Drosophila after infection by Photorhabdus decreased at $30 \mathrm{~h}$. The decrease in AMPs expression could reflect the ability of Photorhabdus to degrade the host AMPs. Of the cytotoxic phospholipase C, protease, proelastase, and hemolysins in OMVs of P. aeruginosa, Proteus mirabilis, and Serratia marcescens [6], known to destroy the membrane of eukaryotic cells [38]. Insect AMPs are synthesized after direct and indirect recognition of pathogens by the haemocytes [39] and fat bodies [40]. However, destruction of haemocytes by OMPs may have partly led to a reduction in AMPs expression. P. luminescens OMPs decreased haemocyte density, after which AMPs expression was limited. X. nematophila OMPs 
elicited total heamocyte population that was initially less than P. luminescens, as was the overall AMPs expression.

Herein, attacin expression was more than cecropin and spodoptericin, the latter, two AMPs possibly being digested by bacterial protease. Purified AMP peptides from G. mellonella (Gm anionic peptide, Gm proline-rich peptide, defensin, a defensin-like and cecropin D-like) and cecropin B from Hyalophora cecropia Linnaeus were sensitive to degradation by elastase B from P. aeruginosa [41-43]. The secreted alkaline metalloprotease (PrtA) produced by Photorhabdus sp. has homologies in P. luminescens and P. temperata that collectively inhibit the activity of G. mellonella cecropins A and B [44]. Photorhabdus PrtS also cleaves insect antibacterial peptides [45]. The alkaline protease of P. aeruginosa may also be responsible for some degradation/inactivation of inducible AMPs in G. mellonella [42]. Live Xenorhabdus inhibits expression of lysozyme and [46], cecropin in S. exigua [47] and purified protease II from X. nematophila reduced $97 \%$ of cecropin A [48].

Generally, humoral and cellular immune defenses of insects are cross-linked. The PLA 2 has an important role in eicosanoid biosynthesis of insects, the eicosanoids affecting aggregation of haemocytes, haemocyte migration, and release of prophenoloxidase from oenocytoids [49]. Thus, the effect of PLA 2 activity leads to a change in cellular and humoral reactions. Here, the OMPs of X. nematophila and P. luminescens decreased PLA 2 activity and probably prevented eicosanoid biosynthesis, since AMPs expression in S. exigua by eicosanoid pathway is inhibited by intact X. nematophila [50].

Herein, the data about the involvement of OMPs of X. nematophila and P. luminescens on S. exigua haemocytes and the expression pattern of main AMPs during are novel for insect pathology. We proposed the role for OMPs in the destruction of haemocytes, modulation of plasma enzymes (PLA 2 and PO) as the main defense source of infected insect. Here, in addition to the haemocyte density and PO activity at interval times, the differential effects of OMPs from X. nematophila and P. luminescens on the number of granulocytes, protease, $\mathrm{PLA}_{2}$ activities, attacin, cecropin, and spodoptericin expression were surveyed and indicated the difference in likely virulent factors between the bacterial species.

In summary, cumulative information suggests that secretion of insect toxins, outer membrane proteins, other extracellular products, and the release of LPS molecules from the bacterial envelope lead to the death of the host. Also, the current work increased our knowledge about the ability of OMPs in the suppression of cellular and humoral defense of insects.

\section{Conclusions}

This study provides a novel insight into some aspects of immune defense of S. exigua larvae against outer membrane proteins of $X$. nematophila and P. luminescens. The obtained results indicated that OMPs of symbiotic bacteria affected on cellular and humoral immune system. But there were differences between them. The current work increased us knowledge about the pathogenicity of $X$. nematophila and P. luminescens.

Supplementary Materials: The following are available online at http://www.mdpi.com/2075-4450/10/10/352/s1, Figure S1. Changes of oenocytoids in fifth instar larvae of Spodoptera exigua after injection with outer membrane proteins of Photorhabdus luminescens. Figure S2. Chnages of oenoctyoids in last instar larvae of Spodoptera exigua after injection with outer membrane proteins of Xenorhabdus nematophil. Figuree S3. Fluctuation pattern of plasmatocytes in fifth instar larvae of Spodoptera exigua after injection with outer membrane proteins of Photorhabdus luminescens. Figure S4 Changes of plasmatocytes in the last larvae of Spodoptera exigua after injection with outer membrane proteins of Xenorhabdus nematophil. Figure S5. Changes of spherulocytes in fifth instar larvae of Spodoptera exigua after injection with outer membrane proteins of Photorhabdus luminescens. Figure S6. Fluctuation pattern of spherulocytes in last instar larvae of Spodoptera exigua after injection with outer membrane proteins of Photorhabdus luminescens.

Author Contributions: Conceptualization, J.K.; methodology, R.D. and J.K.; data acquisition, R.D.; analysis, R.D., J.K. and G.B.D.; original draft preparation, R.D. and J.K.; review \& editing, all authors; supervision, J.K. and G.B.D.; project administration, R.D. and J.K.; funding acquisition, J.K.

Funding: The Iran National Science Foundation (project No. 97001987) and Research Deputy of Ferdowsi University of Mashhad (grant no. 6233/2017) financially supported the project. 
Acknowledgments: The authors appreciate from Iran National Science Foundation for support the project No. 97001987. Thanks are also due to Mojtaba Hosseini for its assist. We appreciate editor and reviewers which improved the manuscript.

Conflicts of Interest: The authors declare no conflict of interest.

\section{References}

1. Gaugler, R. Matching Nematode and Insect to Achieve Optimal Field Performance, in Optimal Use of Insecticidal Nematodes in Pest Management; Polavarapu, S., Ed.; Rutgers University: New Brundwick, NJ, USA, 1999; pp. 9-14.

2. Akhurst, R.J.; Dunphy, G.B. Tripartite Interactions Between Symbiotically Associated Entomopathogenic Bacteria, Nematodes, and Their Insect Hosts, in Parasites and Pathogens of Insects; Beckage, N.E., Thompson, S.N., Federich, B.A., Eds.; Académie Press: San Diego, CA, USA, 1993; pp. 1-23.

3. Brown, S.E.; Cao, A.T.; Dobson, P.; Hines, E.R.; Akhurst, R.J.; East, P.D. Txp40, a ubiquitous insecticidal toxin protein from Xenorhabdus and Photorhabdus bacteria. Appl. Environ. Microbiol. 2006, 72, 1653-1662. [CrossRef] [PubMed]

4. Kumari, P.; Kant, S.; Zaman, S.; Kumar Mahaparto, G.; Banerjee, N.; Bhalla Sarin, N. A novel insecticidal GroEL protein from Xenorhabdus nematophila confers insect resistance in tobacco. Transgenic. Res. 2014, 23, 99-107. [CrossRef] [PubMed]

5. Eleftherianos, I.; Boundy, S.; Joyce, S.A.; Aslam, S.; Marshall, J.W.; Cox, R.J.; Simpson, T.J.; Clarke, D.J.; ffrench-Constant, R.H.; Reynolds, S.E. An antibiotic produced by an insect-pathogenic bacterium suppresses host defenses through phenoloxidase inhibition. Proc. Natl. Acad. Sci. USA 2007, 104, 2419-2424. [CrossRef] [PubMed]

6. Beveridge, T.J. Structures of Gram-negative cell walls and their derived membrane vesicles. J. Bacteriol. 1999, 181, 4725-4733. [PubMed]

7. Rollauer, A.E.; Sooreshjani, M.A.; Noinaj, N.; Buchanan, S.K. Outer membrane protein biogenesis in Gram-negative bacteria. Philos. Trans. R. Soc. B 2015, 370. [CrossRef] [PubMed]

8. Forst, S.; Nealson, K. Molecular Biology of the Symbiotic-Pathogenic Bacteria Xenorhabdus spp. and Photorhabdus spp. Microbiol. Rev. 1996, 60, 21-43. [PubMed]

9. Ruisheng, A.; Sreevatsan, S.; Grewal, P. Comparative in vivo gene expression of the closely related bacteria Photorhabdus temperata and Xenorhabdus koppenhoeferi upon infection of the same insect host, Rhizotrogus majalis. BMC Genomics 2009, 10, 433.

10. Park, Y.; Choi, Y.; Kim, Y. An entomopathogenic bacterium, Xenorhabdus nematophila, causes hemocyte apoptosis of beet armyworm, Spodoptera exigua. J. Asia Pac. Entomol. 2005, 8, 153-159. [CrossRef]

11. Park, Y.; Kim, Y. Xenorhabdus nematophilus inhibits p-bromophenacyl bromide (BPB)-sensitive PLA 2 of Spodoptera exigua. Arch. Insect. Biochem. Physiol. 2003, 54, 134-142. [CrossRef]

12. Wilson, R.; Chen, C.; Ratcliffe, N.A. Innate immunity in insects: The role of multiple, endogenous serum lectins in the recognition of foreign invaders in the cockroach, Blaberus discoidalis. J. Immunol. 1999, 162, $1590-1596$.

13. Korhonen, T.; Nurmiaho, E.L.; RanTan, H.; Eden, C.S. New method for isolation of immunologically pure pili from Escherichia coli. Infect. Immun. 1980, 27, 569-575. [PubMed]

14. Jones, J.C. Changes in the hemocyte picture of Galleria mellonella L. Biol. Bull. 1967, 132, 211-221. [CrossRef] [PubMed]

15. Altuntas, H.; Kilic, A.Y.; Uckan, F.; Ergin, E. Effects of gibberellic acid on haemocytes of Galleria mellonella L. (Lepidoptera: Pyralidae). Environ. Entomol. 2012, 41, 688-696. [CrossRef] [PubMed]

16. Gupta, A.P. Insect Hemocytes; Cambridge University Press: New York, NY, USA, 1979.

17. Ribeiro, C.; Brehélin, M. Insect haemocytes: What type of cell is that? J. Insect. Physiol. 2006, 52, 417-429. [CrossRef] [PubMed]

18. Gholamzadeh Chitgar, M.; Ghadamyari, M.; Sharifi, M. Identification and characterisation of gut proteases in the fig tree skeletoniser moth, Choreutis nemorana Hübner (Lepidoptera: Choreutidae). Plant. Protect. Sci. 2013, 49, 19-26. [CrossRef] 
19. Radvanyi, F.; Jordan, L.; Russo-Marie, F.; Bon, C. A sensitive and continuous fluorometric assay for phospholipase $\mathrm{A}_{2}$ using pyrene-labeled phospholipids in the presence of serum albumin. Anal. Biochem. 1989, 77, 103-109. [CrossRef]

20. Bradford, M.M. A rapid and sensitive method for the quantitating of microgram quantities of protein utilizing the principle of protein-dye binding. Anal. Biochem. 1976, 72, 248-254. [CrossRef]

21. Rahatkhah, Z.; Karimi, J.; Ghadamyari, M.; Brivio, M.F. Immune defense of Agriotes lineatus larvae against. BioControl 2015, 60, 641-653. [CrossRef]

22. Darsouei, R.; Karimi, J.; Ghadamyari, M.; Hosseini, M. Differential change patterns of main antimicrobial peptide genes during infection of entomophathogenic nematode and their symbiotic bacteria. J. Parasitol. 2017, 103, 349-358. [CrossRef]

23. Livak, K.J.; Schmittgen, T.D. Analysis of relative gene expression data using Real Time quantitative PCR and the $2^{\wedge} \Delta \Delta \mathrm{CT}$ method. Methods 2001, 25, 402-408. [CrossRef]

24. SAS Institute. SAS/STAT User's Guide, Release 6.03; SAS Institute: Cary, NC, USA, 1989.

25. Tsuzuki, S.; Matsumoto, H.; Furihata, S.; Ryuda, M.; Tanaka, H.; Sung, E.J.; Bird, G.S.; Zhou, Y.; Shears, S.B.; Hayakawa, Y. Switching between humoral and cellular immune responses in Drosophila is guided by the cytokine GBP. Nat. Commun. 2014, 18, 4628. [CrossRef]

26. Dunphy, G.B.; Halwani, A.E. Haemolymph proteins of larvae of Galleria mellonella detoxify endotoxins of the insect pathogenic bacteria Xenorhabdus nematophila (Enterobacteriaceae). J. Insect Physiol. 1997, 43, 1023-1029. [CrossRef]

27. Dunphy, G.B.; Webster, J.M. Lipopolysaccharides of Xenorhabdus nematophilus and their haemocyte toxicity in non-immune Galleria mellonella (Insecta: Lepidoptera) larvae. J. Gen. Microbiol. 1998, 134, 1017-1028. [CrossRef]

28. Shrestha, S.; Kim, Y. Eicosanoids mediate prophenoloxidase release from oenocytoids in the beet armyworm Spodoptera exigua. Insect. Biochem. Mol. Biol. 2008, 38, 99-112. [CrossRef]

29. Leisman, G.B.; Waukau, J.; Forst, S.A. Characterization and environmental regulation of outer membrane proteins in Xenorhabdus nematophilus. Appl. Environ. Microbiol. 1995, 61, 200-204.

30. Khandelwal, P.; Choudhury, D.; Birah, A.; Reddy, M.L.; Gupta, G.P.; Banerjee, N. Insecticidal pilin subunit from the insect pathogen Xenorhabdus nematophila. J. Bacteriol. 2004, 186, 6465-6476. [CrossRef]

31. Khandelwal, P.; Banerjee-Bhatnagar, N. Insecticidal Activity Associated with the Outer Membrane Vesicles of Xenorhabdus nematophilus. Appl. Environ. Microbiol. 2003, 69, 2032-2037. [CrossRef]

32. Papamichail, D.; Delihas, N. Outer membrane protein genes and their small non-coding RNA regulator genes in Photorhabdus luminescens. Biol. Direct. 2006, 1, 12. [CrossRef]

33. Wang, Y.; Zhang, P.; Fujii, H.; Banno, Y.; Yamamoto, K.; Aso, Y. Proteomic studies of lipopolysaccharide-induced polypeptides in the silkworm, Bombyx mori. Biosci. Biotechnol. Biochem. 2004, 68, 1821-1823. [CrossRef]

34. Duperthuy, M.; Binesse, J.; Le Roux, F.; Romestand, B.; Caro, A.; Got, P.; Givaudan, A.; Mazel, D.; Bachere, E.; Delphine, D.G. The major outer membrane protein OmpU of Vibrio splendidus contributes to host antimicrobial peptide resistance and is required for virulence in the oyster Crassostrea gigas. Environ. Microbiol. 2010, 12, 951-963. [CrossRef]

35. Vanaja, S.K.; Russo, A.J.; Behl, B.; Banerjee, I.; Yankova, M.; Deshmukh, S.D.; Rathinam, V.A.K. Bacterial outer membrane vesicles mediate cytosolic localization of LPS and caspase-11 activation. Cell 2016, 165, 1106-1119. [CrossRef]

36. Yi, H.Y.; Chowdhury, M.; Huang, Y.D.; Yu, X.Q. Insect antimicrobial peptides and their applications. Appl. Microbiol. Biotechnol. 2014, 98, 5807-5822. [CrossRef]

37. Castillo, J.C.; Creasy, T.; Kumari, P.; Shetty, A.; Shokal, U.; Tallon, L.J.; Elertherianos, L. Drosophila anti-nematode and antibacterial immune regulators revealed by RNA-Seq. BMC Genomics 2015, 16, 1-21. [CrossRef]

38. Chen, Y.; Chen, M.; Zhang, Y.; Lee, J.H.; Escajadillo, T.; Fang, R.H.; Gao, W.; Nizet, V.; Zhang, L. Broad-Spectrum neutralization of pore-forming toxins with human erythrocyte membrane-coated nanosponges. Adv. Healthc. Mater. 2018. [CrossRef]

39. Hoffmann, J.A.; Kafatos, F.; Janawey, C.; Ezekovitz, R.A.B. Phylogenetic perspectives in innate immunity. Science 1999, 284, 1313-1318. [CrossRef] 
40. Lemaitre, B.; Hoffmann, J. The host defense of Drosophila melanogaster. Annu. Rev. Immunol. 2007, 25, 697-743. [CrossRef]

41. Mak, P.; Chmiel, D.; Gacek, G.J. Antibacterial peptides of the moth Galleria mellonella. Acta. Biochim. Pol. 2001, 48, 1191-1195.

42. Andrejko, M.; Mizerska-Dudka, M. Elastase B of Pseudomonas aeruginosa stimulates the humoral immune response in the greater wax moth, Galleria mellonella. J. Invertebr. Pathol. 2011, 107, 16-26. [CrossRef]

43. Kadurugamuwa, J.; Beveridge, T.J. Virulence factors are released from Pseudomonas aeruginosa in association with membrane vesicles during normal growth and exposure to gentamicin: A novel mechanism of enzyme secretion. J. Bacteriol. 1995, 177, 3998-4008. [CrossRef]

44. Cabral, C.M.; Cherqui, A.; Pereira, A.; Simoes, N. Purification and characterization of two distinct metalloproteases secreted by the entomopathogenic bacterium Photorhabdus sp. strain Az29. Appl. Environ. Microbiol. 2004, 70, 3831-3838. [CrossRef]

45. Held, K.G.; LaRock, C.N.; Argenio, D.A.; Berg, C.A.; Collins, C.M. A metalloprotease secreted by the insect pathogen Photorhabdus luminescens induces melanization. Appl. Environ. Microbiol. 2007, 73, 7622-7628. [CrossRef] [PubMed]

46. Dickinson, L.; Russell, V.; Dunn, P.E. A family of bacteria-regulated, cecropin D-like peptides from Manduca sexta. J. Biol. Chem. 1988, 263, 19424-19429. [PubMed]

47. Ji, D.; Kim, Y. An entomopathogenic bacterium, Xenorhabdus nematophila, inhibits the expression of an antibacterial peptide, cecropin, of the beet armyworm, Spodoptera exigua. J. Insect. Physiol. 2004, 50, 489-496. [CrossRef] [PubMed]

48. Caldas, C.; Cherqui, A.; Pereria, A.; Simoes, N. Purification and characterization of an extracellular protease from Xenorhabdus nematophila involved in insect immunosuppression. Appl. Environ. Microbiol. 2002, 68, 1297-1304. [CrossRef]

49. Stanley, D.W.; Goodman, C.; An, S.; Song, Q. Prostaglandin A2 influences gene expression in an established insect cell line (BCIRL-HzAM1) cells. J. Insect. Physiol. 2012, 58, 837-849. [CrossRef]

50. Hwang, J.; Park, Y.; Kim, Y. An entomopathogenic bacterium, Xenorhabdus nematophila, suppresses expression of antimicrobial peptides controlled by Toll and IMD pathways by blocking eicosanoid biosynthesis. Arch. Insect Biochem. Physiol. 2013, 83, 151-169. [CrossRef]

(C) 2019 by the authors. Licensee MDPI, Basel, Switzerland. This article is an open access article distributed under the terms and conditions of the Creative Commons Attribution (CC BY) license (http://creativecommons.org/licenses/by/4.0/). 